УДК 316.6.

12.00.00 Юридические науки

МОЛОДЕЖНАЯ ДЕВИАНТНОСТЬ КАК РЕЗУЛЬТАТ ВОСПРОИЗВОДСТВА ПОЛИТИКОПРАВОВОГО НИГИЛИЗМА В УСЛОВИЯХ ИЗБИРАТЕЛЬНОГО ПРОЦЕССА РОССИИ

Чапурко Татьяна Михайловна

к.ю.н., д.полит.н., профессор кафедры уголовного права

Великая Виктория Олеговна

преподаватель кафедры физвоспитания

Сухова Диана Валерьевна

аспирант кафедры уголовного права

Чикаленко Наталья Борисовна

аспирант кафедры уголовного права

Кубанский государственный аграрный универси-

тет, Краснодар, Россия

В современной России так и не созданы важнейшие институты политического и социального развития, необходимые для вовлечения молодых граждан в общественно-политическую и правовую жизнь, и весьма большие нарекания вызывает «эффективность проведения судебной реформы» и результаты противодействия системной коррупции, без которых сложно рассчитывать на результативное снижение уровня политического и правового нигилизма среди молодежи. Рассмотрению связанных с этим проблем и подходам к их решению и посвящена данная статья

Ключевые слова: МОЛОДЕЖНАЯ ДЕВИАНТНОСТЬ КАК РЕЗУЛЬТАТ ВОСПРОИЗВОДСТВА ПОЛИТИКО-ПРАВОВОГО НИГИЛИЗМА В УСЛОВИЯХ ИЗБИРАТЕЛЬНОГО ПРОЦЕССА РОССИИ

Doi: 10.21515/1990-4665-134-101
UDC 316.6.

Legal sciences

\section{YOUTH DEVIANCE AS A RESULT OF THE REPRODUCTION OF POLITICAL AND LEGAL NIHILISM IN TERMS OF THE ELECTORAL PROCESS IN RUSSIA}

Chapurko Tatyana Mikhailovna

Cand.Leg.Sci., Dr.Sci.Polit., Professor of the Criminal law Department

Velikaya Victoria Olegovna

lecturer of the Department of physical education

Sukhova Diana Valerievna

post-graduate student of the Chair of criminal law

Chykalenko Natalia Borisovna

post-graduate student of the Chair of criminal law Kuban state agrarian University, Krasnodar, Russia

In modern Russia, there were not created key institutions of political and social development needed to involve young citizens in political and legal life, and very serious criticism is "the effectiveness of judicial reform" and the results of combating systemic corruption, without which it is difficult to count on the impact of the decrease in the level of political and legal nihilism among young people. The review of related problems and approaches to their solution are addressed in this article

Keywords: YOUTH DEVIANCE AS A RESULT OF THE REPRODUCTION OF POLITICAL AND LEGAL NIHILISM IN TERMS OF THE ELECTORAL PROCESS IN RUSSIA

Современные условия жизни российского молодежного общества представляет собой сложнейшие процессы взаимосвязи материальных, правовых, политических, духовных интересов различных индивидов и групп людей. Социальная неоднородность общества, проявляющаяся в различии уровней доходов, собственности, власти, престижа, в горизонтальной и вертикальной мобильности, закономерно приводит к обострению общественных противоречий и конфликтов. Именно социальная де- 
стабилизация вызывает всплеск девиантности, обостряет крайние (маргинальные) формы ее проявления, продуцируя эскалацию социального диспаритета вкупе с другими негативными процессами, стимулирует преступность, которая в XXI в. превратилась в одну из самых сложных социальных проблем. Сама жизнь современного социума обозначила необходимость дальнейшего совершенствования правовой базы для регулирования экстремальных процессов в обществе. И решение данных проблем невозможно без знания социально - психологической специфики экстремальной среды и понимания ее как целостного социального явления, имеющего свои закономерности ${ }^{1}$.

Необходимо признать, что в стране так и не сложился институт общественного контроля за правоохранительными органами, именно контроля, а не вмешательства, что является одним из факторов воспроизводства политико-правового нигилизма. Отсутствуют акторы, заинтересованные в создании в стране предсказуемой и четкой судебно-правовой системы.

Современный период общественного развития XXI века уже диктует необходимость поиска новых возможностей постижения политико - криминологических и социально-правовых явлений на стыке естественных и общественных наук. Поэтому обратимся к тем личностным позициям в обществе, от которых во многом и зависит криминализация общества, в особенности молодежной части. Так, в системе факторов, влияющих на состояние законности и правопорядка в обществе и государстве, значительное место занимает уровень правовой культуры, правосознания и правового воспитания личности у различных социальных групп населения. Законность же, как строгое соблюдение законов и подзаконных правовых актов, всеми без исключения организациями, должностными лицами и граждана-

\footnotetext{
${ }^{1}$ Чапурко Т.М., Пилюгина Т.В., Иващенко Н.П. Современная молодежная преступность - результат политико-правового нигилизма в России // Экономика. Право. Печать: Вестник КСЭИ № 4(60) 2013
} 
ми, являясь основополагающим принципом правового регулирования в государстве, формирует определенный режим общественной жизни, метод государственного руководства, который состоит в организации общественных отношений с помощью не только законов и других правовых актов, но и складывающихся и утверждающихся криминальных установок (в виде лексикона разговорной речи, отношения к общественному порядку, поведения в общественном месте и т.д.).

Поэтому, если рассматривать тему реформирования судебной и правоохранительной системы как некий месседж власти населению, то это послание воспринимается гражданами со значительной долей скептицизма, поскольку люди не видят системных изменений. Такой дискурс объясним в ходе реализуемой в стране судебной реформы и реформирования правоохранительной системы представители элиты решают сиюминутные политические задачи, а интересы граждан не более чем политическая декларация, не подкрепленная реальными шагами по устранению системных дисфункций в деятельности органов правопорядка.

Так, профессор Академии народного хозяйства при Правительстве Российской Федерации А. Пригожин констатировал, что «Пренебрежение правовым содержанием законов и есть беззаконие. А оно имеет столь тяжкие следствия, что кто-то когда-то вынужден будет заняться переходом к правовому государству, потому что беззаконие рождает страх перед властью и ее представителями. Страх создает в обществе много стрессов и фобий, репрессивную культуру. Он обессиливает общество, искажает обратную связь в государстве. Наш бизнес никогда не станет развитым, эффективным в этих условиях. Беззаконие порочит страну, унижает, вызывает насмешки и неуважение к нам в развитом мире. Так складывается антиинновационная среда, где творческим людям дискомфортно жить и ра- 
ботать. Законность есть качество жизни. Без правового государства невозможно одолеть отсталость» ${ }^{2}$.

Однако для делинквентно ориентированной части бюрократии не существует угрозы статусных потерь в случае нарастания в обществе политико-правового нигилизма. На взгляд авторов внутри политической элиты существуют группы, которые можно назвать реакционными и именно они представляют угрозу для политической модернизации осуществление которой, в частности, позволило бы снизить в стране уровень политикоправового нигилизма молодежи. Так, немецкий политолог Йоханнес Фосвинкель пишет, что «Демонстративный произвол властей, использующих закон исключительно как свое оружие в политической борьбе и стяжательстве, окончательно выхолостил и без того дырявое правовое российское государство». Как отмечает Й.Фосвинкель, тысячи сомнительных приговоров ежегодно выносятся в отношении предпринимателей, чтобы завладеть их имуществом, офисными зданиями, товарными складами или земельными участками. «За этим стоят организованные группы рейдеров, региональные чиновники, продажные прокуроры, коррумпированные полицейские и послушные судьи» ${ }^{3}$.

В таких условиях гражданина лишают основных прав де-факто представители местной элиты при попустительстве сотрудников правоохранительных органов, что выступает в качестве детерминанты политической аномии.

«Именно в такой ситуации политическое насилие рано или поздно входит в число допустимых средств ведения политической борьбы - если не одобряемых, то с сочувствием принимаемых обществом. Сейчас проявления такого насилия похожи на стихийные поступки одиночек с не всегда внятным идеологическим посылом. Но эти одиночки не так одиноки, а

\footnotetext{
${ }^{2}$ Пригожин А. Час икс: Право выше закона // Ведомости, 2010, № 203 (2721), 27.10.

${ }^{3}$ Voswinkel J. Fall Chodorkowskij - letzte Runde einer Justiz-Farce // Die Zeit, 2011, 25.5.
} 
идеологическая кристаллизация не такое уж хитрое дело. Тем более что готовые предложить свои услуги могут найтись на самых разных политических флангах» ${ }^{4}$.

По мнению авторов в случае эскалации политического насилия - у политической системы страны нет будущего.

По этому поводу известный отечественный политолог Г. Павловский констатирует, что «В России на месте государства, которое бы отличало себя от общества, находится власть, неотличимая от схемы социальной реальности. Здесь для того, чтобы защититься, нужно самому прибегнуть к насилию, либо перейти под защиту кого-то, кто насилие практикует» ${ }^{5}$ что в современных условиях проявляют молодежные группировки.

Так, 22-25 октября 2015 года Аналитический Центр Юрия Левады (Левада-Центр) провел опрос по репрезентативной выборке 1600 россиян в возрасте 18 лет и до 35 лет в 127 населенных пунктах 44 регионов страны. Распределение ответов на некоторые вопросы исследования приводятся в процентах от общего числа опрошенных вместе с данными предыдущих опросов ${ }^{6}$. Статистическая погрешность данных этих исследований не превышает 3,4\%. И 60\% молодых россиян не удовлетворены работой полиции, а в обратном признались только $27 \%$ опрошенных. Также $60 \%$ считают, что усилия полиции в данный момент в основном сосредоточены на обеспечении собственных интересов; в августе этого года так думали на $12 \%$ меньше. Только $24 \%$ верят в то, что полиция занимается защитой граждан, что, однако, на 8\% меньше показателей августа этого года. Среди наиболее лояльно настроенных большинство молодежи до 24-х лет (31\%) и обеспеченных граждан (29\%).

\footnotetext{
${ }^{4}$ Кувалдин С. Желание разбрасывать камни // Эксперт, 2011, №18 (752).

${ }^{5}$ Павловский Г. Новая политкорректность - против языка вражды // Русский журнал, 2010, 22 ноября.

${ }^{6}$ Отношение россиян к полиции // Пресс-релиз Аналитического Центра Юрия Левады (Левада-Центр), 2016, 11 ноября.
} 
Далее, достаточно показательно, что 57\% опрошенных молодых людей охарактеризовали деятельность полиции как оставшуюся на таком же уровне (чаще так отвечали москвичи (67\%) и респонденты в возрасте 2535 лет (66\%)). По мнению 15\% - ситуация улучшилась, а 16\% - ухудшилась. Еще 13\% - затруднились ответить на такой вопрос.

Далее по данным статистики за 2010-2016 годы число молодых предпринимателей, привлеченных к уголовной ответственности за преступления экономической направленности, составило 14,87 \% от общего числа зарегистрированных в стране субъектов экономической деятельности $^{7}$. Так, только в 2010 году сотрудниками МВД РФ были инициированы уголовные дела более чем по 90 тысячам «преступлений» экономической направленности, и в значительной доле этих дел отсутствуют потерпевшие ${ }^{8}$.

Отсутствие в России правовой защиты - это главнейший фактор, отделяющий ее от более благополучных государств, в число которых она стремится войти. Над новой стратегией развития, в которой важное место станет занимать стимулирование экономической и социальной активности граждан, власть не работает, а существующие правовые практики имеют политическую составляющую, что еще больше способствует развитию в обществе аномии.

Последствия для политической системы оказываются не менее драматическими. Так, еще осенью 2007 года страх перед необходимостью уйти от власти (разве в демократической стране президенты и премьеры боятся уходить?) заставил Президента РФ Путина В.В. окончательно разрушить систему выборов в российский парламент. Большая часть государственного строительства последних лет связана только с одной задачей сохранением политического status quo... По тем же причинам соображе-

\footnotetext{
${ }^{7}$ Состояние преступности в России: Статистический сборник за 2010-2016гг. ГИАЦ ИВД России. 2017.

${ }^{8}$ Цит. по: Безвольные предложения. Представители самой крупной фракции Госдумы высказались против проекта амнистии // Российская газета, 2011, 1 июня.
} 
ния личной преданности становятся год от года все более важными. Надо ли говорить, что система, заточенная только на сохранение status quo, оказывается максимально неэффективной, когда речь идет о какой-то модернизации? На восстановление нормальной системы государственного управления потребуется как минимум один-два избирательных цикла целое десятилетие» ${ }^{9}$. И в преддверии выборов 2018 года в этом еще более можем убедиться.

В данном случае мы подошли к проблеме восприятия легитимированного насилия, по поводу которого весьма категорично высказалась член Общественной палаты Российской Федерации и руководитель Новосибирского регионального общественного фонда «Социум» Н.Вавилина, что «в данном случае проблема не только в отношениях «человек-власть», здесь мы должны обратить внимание на другой тревожный симптом. Таких случаев, когда у нас безжалостно топчут слабых, все больше. А причина этого кроется в жестоком обращении с детьми, которое мы допустили на определенном этапе развития нашего общества. Насилие, как известно, порождает насилие. Мы переступили черту и начали проявлять жестокость по отношению к самым незащищенным - и эта жестокость неминуемо распространится на всех остальных» ${ }^{10}$.

В данном же направлении о борьбе с «политико-правовым нигилизмом» политолог Д. Муратов отмечает «позитивные сдвиги», указывая на то, что часть российского судейского корпуса осознала свою независимость, гарантированную Конституцией Российской Федерацией ${ }^{11}$. «Правовой нигилизм в России означает, что закон трактуется в соответствии с

\footnotetext{
${ }^{9}$ Сонин К. Правила игры: Последствия страха // Ведомости, 2010, № 215 (2733), 15.11.

${ }^{10}$ Шулепова Е. Мэров бьют молча. В Рязанской и Тульской областях избили глав муниципальных // Российская газета - Федеральный выпуск, 2010, №5357 (278) от 9 декабря.

${ }^{11}$ Конституция Российской Федерации, принятая референдумом 12 декабря 1993 года с изм и доп 2009 и 2014гг. // Российская газета. 1993. 25 декабря.
} 
интересами. И в течение года это положение вещей не изменить», - замечает Дмитрий Муратов ${ }^{12}$.

Социологические опросы показывают, что молодые российские граждане чувствуют себя неуютно в среде, которая требует индивидуальной ответственности, в связи с чем впадают в различного рода неблагоприятные ситуации ${ }^{13}$. Однако реальных шагов по искоренению политической аномии так и не было предпринято, поскольку речь идет о системной проблеме, в молодые люди «продолжают бояться сотрудничать со следствием. Оправдан ли их страх? Конечно, их страх оправдан. В такой чрезвычайной ситуации в стране должны быть выработаны определенные правовые алгоритмы действий. Наверно, нужно вернуться к идее закона «О борьбе с организованной преступностью» или ввести правовое понятие «антимафиозная операция» или «операция по борьбе с организованной преступностью». Точно так же, как прописана «контртеррористическая операция» в федеральном законе «О противодействии терроризму» ${ }^{14}$.

Считаем, что для исправления положения необходимо в кратчайшие сроки добиться серьезных подвижек по многим ключевым направлениям взаимодействий правоохранительных органов с населением.

Подчеркнем, что ведя речь о феномене преступного явления, и мы на самом деле затрагиваем системные вопросы функционирования правоохранительных институтов. Социологические опросы выявляют достаточно тревожную ситуацию, свидетельствующую о том, что политикоправовой нигилизм значительной молодежной части российского населения лишь отражает современные реалии повседневности.

\footnotetext{
${ }^{12}$ Цит. по: Donath K.-H. Dmitri Muratow über den Fall Chodorkowski "Die Oligarchen sind fetter geworden" // Die Tageszeitung, 2010, 15.12

13 Зелик В.А. Основные тенденции влияния незаконного потребления наркотических средств и психотропных веществ на преступность. Политематический сетевой электронный научный журнал Куб ГАУ. 2014. № 104; Зелик В.А., Яблочкин А.Е. Особенности семейно-бытовых преступлений, совершаемых в состоянии опьянения // Общество и право. 2014. № 4 (50). С.170-174.

${ }^{14}$ Цит. по: Кошкина А. Советник председателя Конституционного суда РФ генерал-майор милиции в отставке Владимир Овчинский «Организованная преступность бесчинствует в большинстве регионов России» // Новые Известия, 2010, 25 ноября.
} 
Однако реальных шагов к снижению политико-правового нигилизма сделано не было и вина в такой ситуации в значительной мере лежит на власти и на политических партиях, которые обязаны проводить в жизнь ценности демократического государства (так, Цапок и Цеповяз были членами «Единой России»). Возникает вопрос - надо что-то менять в партийной системе?

И на этот вопрос советник председателя Конституционного суда РФ генерал-майор милиции в отставке, доктор юридических наук Владимир Овчинский ответил следующим образом: «Я не член «Единой России», но когда я был членом КПСС, проводилось тщательное партийное расследование на всех уровнях. По каждому факту преступления должно быть партийное расследование помимо уголовного. Нужно установить, кто их включил в списки, кто с ними контактировал, кто их лоббировал.... Это происходит потому, что криминал рвется во власть. И не только в партии, но и избирательные комиссии» ${ }^{15}$.

Отсутствие суровой реакции Центра, на взгляд Злобина, выглядит неоправданным в условиях, когда выяснилось, что нулевые оказались еще более криминальными, чем пресловутые 90-е: «Преступность становится фактором публичной политики. И Медведеву, конечно, надо что-то делать, иначе криминальная революция, о которой говорили еще в 80-х, наконец победит» ${ }^{16}$.

По мнению авторов, процитированная угроза вполне реальна и на ближайшие годы, так как прошедшие шесть лет в полной мере определили свободу криминалу и заигрывание с ним.

В итоге, транзитивной России так и не удалось перенять демократию и принцип верховенства закона у стран со стабильными политико-

\footnotetext{
${ }^{15}$ Цит. по: Кошкина А. Советник председателя Конституционного суда РФ генерал-майор милиции в отставке Владимир Овчинский «Организованная преступность бесчинствует в большинстве регионов России» // Новые Известия, 2010, 25 ноября.

${ }^{16}$ Цит. по: Самарина А. Убийство как засада для власти. Медведеву надо что-то делать, иначе криминальная революция наконец победит// Независимая газета, 2010, 30 ноября.
} 
правовыми режимами. Понимание необходимости системного реформирования правоохранительных органов в контексте уменьшения в обществе политической аномии подразумевает комплексный подход к исследованию политического восприятия, учитывающий политико-культурные, пространственные, темпоральные, субъектные и политико-психологические аспекты реформы государственной власти. При этом сама по себе постановка проблемы снижения политико-правового нигилизма на уровне исполнительной власти совершенно необходима. Общество эту проблему не только осознало, оно к ней привыкло, что относится авторами к числу угроз национальной безопасности.

Принимаемые политико-правовые меры по уменьшению уровня молодежного нигилизма должны способствовать улучшению взаимоотношений между сотрудниками полиции и иных правоохранительных органов с гражданами. Чиновники рассчитывают, что нововведения в процессе проводимого реформирования помогут полиции избавиться от негативного образа коррумпированной структуры с некомпетентными сотрудниками, однако без решения проблемы политического нигилизма граждан, затраченные ресурсы не дадут эффекта.

В итоге, как было обозначено и пытались доказать по проведенному исследовании, что политико-правовой нигилизм разрушает общество изнутри - если нет общих правил игры, то коллективно жить нельзя, а человек все-таки существо коллективное.

Находящиеся во власти политики не в состоянии адаптироваться к изменению структуры социального риска, поэтому требуется группа людей с новыми знаниями и умениями. Иначе общество будет долгое время иметь дело с консервативным политическим дискурсом правящей элиты, для которого характерно сочетание: никаких реально решаемых институциональных проблем связанных с модернизацией, никаких решений ори- 
ентированных на повышение политической активности масс, никаких системных реформ.

Политическая элита на своем примере должна демонстрировать обществу правовое самосознание, однако достаточно часто этого на практике не наблюдается. Для всего этого требуется политическая воля.

Кроме того масс-медиа общественно-политической направленности в современной России несут ответственность за нарастание в коллективном бессознательном политико-правового нигилизма, в частности, современные фильмы про полицейских, которые сами на каждом шагу нарушают закон, пусть и ради более высокой цели, пропагандируют правовой нигилизм, а отнюдь не правовое самосознание.

Политический нигилизм не может быть отделен от моральных выводов и перспективы политического действия (бездействия) в рамках существующего в стране политического поля. На практике указанные в Конституции РФ права нередко нарушаются, что становится одним из основных источников распространения в обществе политического нигилизма.

В политической науке отсутствуют многофакторные объяснительные модели формирования и воспроизводства политического нигилизма, учитывающие эволюцию социума и его представлений о формах участия в политических действиях. Такого рода модели должны исходить из примата обеспечения прав человека и выявления дисфункций препятствующих их реализации. В таком контексте политический нигилизм должен рассматриваться как один из важнейших индикаторов функционирования политической системы.

Неэффективность действий элиты порождает политический нигилизм и служит источником его воспроизводства.

Представители правящей элиты, решившись на конкретный и обстоятельный разговор с обществом на тему причин политического нигилизма значительной части социума, неизбежно будут вынуждены затронуть та- 
кие проблемы, которые уже не оставят ни политической, ни юридической возможности сохранить существующий политический порядок.

Политический нигилизм не может быть отделен от моральных выводов и перспективы политического действия (бездействия) в рамках существующего в стране политического поля все акторов и, а первую очередь, представителей правящей элиты. Результатом низкого уровня политического доверия населения к элите становится снижение политической легитимации власти, а вместе с этим политическим процессом и распространением антиценностей. В свою очередь, дезинтеграция общества способствует росту политического нигилизма.

Необходимо повысить стимулы для частных лиц к участию в публичных дебатах, поскольку в нынешнем виде электоральный процесс это не борьба идей и даже не борьба пиар-технологов. При смене власти позитивный эффект будет стремительно девальвироваться по мере того, как напряженное ожидание конкретных и публичных действий, направленных на очищение «авгиевых конюшен», оставшихся после ухода предыдущей элитной группы (к примеру, после смены несколько сроков находившегося во власти губернатора или мера) в отставку, будет затягиваться, сменяясь раздражением и разочарованием.

На институциональном уровне снижения политического нигилизма существует несколько существенных препятствий. Неэффективное функционирование базовых институтов современного российского общества приводит к низкому уровню безопасности личности и собственности, а также неверие в возможность определять характер политической жизни в стране.

Если избиратели не согласны с действиями какого-то депутата, недовольны им, то положение они не могут изменить, поскольку в России, как и в большинстве стран мира, процедура отзыва отсутствует. Связанное с нарастанием политического нигилизма снижение значимости процедуры 
выборов приводит к резкому уменьшению явки избирателей и, как следствие, к снижению легитимности действующей власти.

Обществу правящая элита предлагает безальтернативные пути достижения целей развития, что отнюдь не способствует расцвету присущего демократическим системам плюрализма. Де-факто множащиеся препятствия на пути регистрации новых партий негативно сказываются на легитимности существующей партийной системы, вызывая недоверие к власти той части граждан, которую не устраивают программные идеи зарегистрированных политических партий. Рост напряженности в обществе, вызванный кризисом социальных ожиданий не сопровождается появлением инструментов горизонтальной и вертикальной мобильности, без которых невозможна модернизация и снижение уровня политического нигилизма.

По указанной причине консолидированным конформным большинством политический нигилизм не воспринимается как институциональная проблема, которую не только необходимо вынести на повестку дня, но и разработать комплекс мер по повышению политико-социальной активности граждан. Проблема, о которой мы ведем речь, присуща не только для России.

Отстранение людей через неполитические механизмы от участия в решении общественно значимых проблем противоречит принципам социальной справедливости, выступающей современным гарантом устойчивости политической и социальной систем государства. Экономическая изоляция нередко является маркером для других форм отчуждения - социального, культурного, политического. Соответственно с ростом маргинализации снижается и легитимность базовых институтов государства.

Низкая легитимность управляемых выборов с каждыми такими выборами превращает российскую власть во все менее легитимную. Результаты же выборов становятся фактором дестабилизации и в таких процессах 
возможно массовое участие граждан считающихся элитой в настоящее время политическими нигилистами.

Выходом из нарастающей нестабильности политической системы является принятие комплекса мер ориентированных на уменьшение политико-правового нигилизма. В первую очередь речь должна идти о повышении правовой грамотности и стимулировании участия граждан в деятельности местных сообществ.

В постсовременной России не созданы важнейшие институты политического и социального развития, необходимые для вовлечения граждан в общественную жизнь, большие нарекания вызывает эффективность проведения судебной реформы и результаты противодействия системной коррупции - без которых сложно рассчитывать на результативное снижение уровня политического нигилизма. Растущий уровень коррупции и антидемократические тенденции угрожают стабильности страны, системная коррупция пропитала бюрократический аппарат и угрожает самой структуре общества, а растущий политический нигилизм становится одной из угроз национальной безопасности. Внутренние корпоративные нормы и правила специфической части государственной машины все больше становятся правилами для всей политической системы государства.

Ответы обществу на имеющие признаки коррупционных деяний факты, может дать только инициированное властями публичное расследование с участием компетентных экспертов гражданского общества, что позволит гражданам поверить в эффективность антикоррупционной деятельности. Пока же низкая эффективность антикоррупционных мер только способствует росту политического нигилизма.

Необходимо перейти от декларативной борьбы с коррупцией к реальным действиям. Реальным выходом из порочного круга системной коррупции может быть создание принципиально другой политической куль- 
туры, основанной не только на страхе перед коррупционерами и возможности получения выгоды от участия в коррупционных практиках.

При осуществлении антикоррупционной стратегии не учитывается политический нигилизм, что негативно сказывается на восприятии социумом реализуемых мер. Противодействие коррупции происходит без учета того, что в современной России сложились институциональные условия для правового и политического нигилизма - прежде всего, связанные с несовершенством законодательства и практики его применения, а также избирательность в применении норм права и практически полное отсутствие контроля общества над действиями правящей элиты.

Первоочередной задачей является противодействие криминализации правоохранительных органов, а также институционального кризиса в целом до уровня более-менее приемлемого для государственной власти и населения. Существующий политический порядок был сформирован в современной России за счет деформации в общественном сознании базовых ценностей правового общества и утраты у значительной части населения доверия к полиции, что выступает в качестве одной из важнейших детерминант политического нигилизма. Без изменения указанных трендов становится невозможной модернизация, а значит и перевод социальнополитической системы на уровень экономически развитых государств.

Выработка правового самосознания займет не год и не два, но если это будет одно из направлений государственной политики, то в течение последующих десяти лет можно психологически переломить политикоправовой нигилизм. При этом необходимо научное сопровождение принимаемых политических решений, а значит и дальнейшее изучение проблематики нигилизма.

В итоге можно утверждать, что социально-политические и правовые исследования общественных явлений сегодня должны решать главную за- 
дачу — устранить криминализацию общества и в особенности молодежной его части.

Поэтому, обратившись к различным толкованиям «нигилизма», предлагаем проанализировать взаимосвязь девиантного, правонарушающего и преступного поведения среди молодежи с проявлениями в их сознании нигилистических идей. Так, правосознание индивида имеет различные дефекты и деформации. В зависимости от характера искажений можно выделить два типа деформаций: репрессивный и криминальный. В случае репрессивной деформации, например, сотрудниками правоохранительных органов овладевает отрицательное отношение к гражданам: цивильное население воспринимается как контингент правонарушителей, для изобличения которых приемлемо применение любых мер, вплоть до несанкционированного насилия. В случае криминальной деформации, например, сотрудники правоохранительных органов, приходят к убеждению, что правонарушения являются вполне приемлемыми способами удовлетворения жизненных потребностей. Обычно криминальная деформация начинается с пьянства, разврата и злоупотребления властью, а затем приводит к смычке с преступными элементами либо полному криминальному перерождению. Дефекты правосознания - это такие недостатки правового сознания, которые свидетельствуют о его несформированности и тенденциозности. Наиболее распространенными дефектами правового сознания являются правовой нигилизм, правовой фетишизм, правовой идеализм, правовой релятивизм, правовой субъективизм и правовой инфантилизм.

Существуют различные формы общественного сознания, при помощи которых люди осознают окружающую их природу, общество. Выделяют политическое, моральное (нравственное), эстетическое, этическое, религиозное и правовое сознание. «Сознание — важнейшая категория фило- 
софии, обозначающая человеческую способность идеального воспроизведения действительности» ${ }^{17}$.

Однако сознание выступает в двух формах: индивидуальной (личностной) и общественной, и понимание сущности сознания находится в прямой зависимости от решения вопроса о взаимоотношении духа и природы, материи и сознания. Поэтому решение проблемы сознания предполагает и выяснение предпосылок его возникновения. Их можно усматривать в свойстве отражения, лежащего в фундаменте материи, свойстве, родственном сознанию. Непосредственной основой сознания является трудовая деятельность. Сознание неотделимо от деятельности, оно возникает в процессе труда, развивается и обогащается под воздействием социокультурной реальности.

Определяющую роль здесь играет практика жизни молодого человека, когда сознание формируется, прежде всего, через знание, составляющее его сердцевину. Поэтому правомерно говорить, что способность человека, обладающего знанием и не обладающего знанием, проявляется выделением себя из окружающего мира и выражается в итоге в противопоставлении себя обществу как субъекта объекту.

Организация государственной власти, укрепление законности и правопорядка напрямую связано с состоянием правосознания, правовой культуры и правового воспитания населения. Успешная политика государства в правовой сфере должна строиться с учетом стройной системы и структуры органов государственной власти, социально-правового состояния общества, отдельных слоев и групп населения, нравственно-психологического климата, распространенных стереотипов массового сознания, способствующих (или препятствующих) становлению, сознанию и развитию криминогенных или антикриминогенных факторов.

\footnotetext{
${ }^{17}$ Краткий философский словарь / авт. А.П. Алексеев, Г.Г. Васильев и др. / под ред. А.П. Алексеева. -М., 1955. С. 355.
} 
Данными общественными потребностями обусловлена разработка проблематики правосознания, правовой культуры и правового воспитания населения, а также механизмов и факторов нормативно-правовой регуляции юридически значимого поведения, которая стала одной из ведущих, концептуальных в юриспруденции.

Между правом как системой норм, с одной стороны, и реальностью поведения человека, предписанным или запрещенным этими нормами, - c другой, находится посредствующее звено - человеческое сознание молодого человека и результаты воздействия на него воспитательных процессов. Отражая социальную действительность, сознание познает и усваивает существующие нормы, определенным образом оценивает их, в той или иной мере руководствуется ими, направляя реальное поведение молодого человека к правопослушным или к правонарушающим формам, либо же в целом к невосприятию существующей социально-правовой и политической системы установок общества и государства.

Таким образом, сознание, являясь непосредственным источником активности и регулятором человеческого поведения, само испытывает регулирующее воздействие внешних явлений, к числу которых относим действующее право, практику его применения, процесс правового воспитания, а также иные явления правовой действительности.

В качестве специальных средств сведения к минимуму правового и политического нигилизма среди молодежи, считаем, следует назвать следующее: обеспечение должного качества принимаемых законов, упрочение законности, проведение судебной реформы в целом на принципах справедливости и доступности, приведение в соответствие с потребностями времени правового воспитания населения, профессионального обучения и воспитания юристов и других профессий. Одновременно необходима систематическая предметная работа по повышению уровня правовой культу- 
ры общества и профессиональной культуры всех субъектов правоохранительной системы.

Юридическая безграмотность молодежи свидетельствует о том, что правосознание данного индивида еще не сложилось, когда какие-то факты, события или поступки никак не связываются в сознании с их юридическим значением, с юридическими последствиями, тогда и проявляется криминализация поведения.

Общество, государство и сами граждане объективно заинтересованы в том, чтобы каждый молодой человек в большей или меньшей мере обладал правовыми знаниями, которые раскрывают содержание, смысл и назначение действующей нормативно-правовой системы, а также помогают уяснить механизм регулирования общественных отношений и рационально использовать его в обновлении России. И весьма жаль, что действующий закон «Об образовании в Российской Федерации» ${ }^{18}$ столько «скромно» отразил свое участие в формировании российской молодежи. Сказанное полностью относится и к вопросу борьбы с преступностью и иными правонарушениями, искоренения антиобщественных проявлений среди молодежи, что также не плодотворно заявлено в законе «Об основах системы профилактики правонарушений в Российской Федерации» ${ }^{19}$.

В итоге можем сказать, что в современной России так и не созданы важнейшие институты политического и социального развития, необходимые для вовлечения молодых граждан в общественно-политическую и правовую жизнь, и весьма большие нарекания вызывает «эффективность проведения судебной реформы» и результаты противодействия системной коррупции, без которых сложно рассчитывать на результативное снижение уровня политического и правового нигилизма среди молодежи.

\footnotetext{
${ }^{18}$ Об образовании в Российской Федерации: Федеральный закон от 29.12.2012 № 273-ФЗ с изм и доп. // Российская газета. 2012. 30 декабря.

${ }^{19}$ Об основах системы профилактики правонарушений в Российской Федерации: Федеральный закон от 23 июля 2016г. № 182-Ф3 // Российская газета. 2016. 25 июня.
} 


\section{Литература}

1. Чапурко Т.М., Пилюгина Т.В., Иващенко Н.П. Современная молодежная преступность - результат политико-правового нигилизма в России // Экономика. Право. Печать: Вестник КСЭИ № 4(60) 2013

2. Пригожин А. Час икс: Право выше закона // Ведомости, 2010, № 203 (2721), 27.10.

3. Voswinkel J. Fall Chodorkowskij - letzte Runde einer Justiz-Farce // Die Zeit, 2011, 25.5.

4. Кувалдин С. Желание разбрасывать камни // Эксперт, 2011, №18 (752).

5. Павловский Г. Новая политкорректность - против языка вражды // Русский журнал, 2010, 22 ноября.

6. Отношение россиян к полиции // Пресс-релиз Аналитического Центра Юрия Левады (Левада-Центр), 2016, 11 ноября.

7. Состояние преступности в России: Статистический сборник за 2010-2016гг. ГИАЦ ИВД России. 2017.

8. Цит. по: Безвольные предложения. Представители самой крупной фракции Госдумы высказались против проекта амнистии // Российская газета, 2011, 1 июня.

9. Сонин К. Правила игры: Последствия страха // Ведомости, 2010, № 215 (2733), 15.11.

10. Шулепова Е. Мэров бьют молча. В Рязанской и Тульской областях избили глав муниципальных // Российская газета - Федеральный выпуск, 2010, №5357 (278) от 9 декабря.

11. Конституция Российской Федерации, принятая референдумом 12 декабря 1993 года с изм и доп 2009 и 2014гг. // Российская газета. 1993. 25 декабря.

12. Цит. по: Donath K.-H. Dmitri Muratow über den Fall Chodorkowski "Die Oligarchen sind fetter geworden" // Die Tageszeitung, 2010, 15.12

13. Зелик В.А. Основные тенденции влияния незаконного потребления наркотических средств и психотропных веществ на преступность. Политематический сетевой электронный научный журнал Куб ГАУ. 2014. № 104; Зелик В.А., Яблочкин А.Е. Особенности семейно-бытовых преступлений, совершаемых в состоянии опьянения // Общество и право. 2014. № 4 (50). С.170-174.

14. Кошкина А. Советник председателя Конституционного суда РФ генерал-майор милиции в отставке Владимир Овчинский «Организованная преступность бесчинствует в большинстве регионов России» // Новые Известия, 2010, 25 ноября.

15. Кошкина А. Советник председателя Конституционного суда РФ генерал-майор милиции в отставке Владимир Овчинский «Организованная преступность бесчинствует в большинстве регионов России» // Новые Известия, 2010, 25 ноября.

16. Самарина А. Убийство как засада для власти. Медведеву надо что-то делать, иначе криминальная революция наконец победит// Независимая газета, 2010, 30 ноября.

17. Краткий философский словарь / авт. А.П. Алексеев, Г.Г. Васильев и др. / под ред. А.П. Алексеева. -М., 1955. С. 355.

18. Об образовании в Российской Федерации: Федеральный закон от 29.12.2012 № 273-ФЗ с изм и доп. // Российская газета. 2012. 30 декабря.

19. Об основах системы профилактики правонарушений в Российской Федерации: Федеральный закон от 23 июля 2016г. № 182-Ф3 // Российская газета. 2016. 25 июня.

\section{References}


1. Chapurko T.M., Piljugina T.V., Ivashhenko N.P. Sovremennaja molodezhnaja prestupnost' - rezul'tat politiko-pravovogo nigilizma v Rossii // Jekonomika. Pravo. Pechat': Vestnik KSJeI № 4(60) 2013

2. Prigozhin A. Chas iks: Pravo vyshe zakona // Vedomosti, 2010, № 203 (2721), 27.10.

3. Voswinkel J. Fall Chodorkowskij - letzte Runde einer Justiz-Farce // Die Zeit, 2011, 25.5.

4. Kuvaldin S. Zhelanie razbrasyvat' kamni // Jekspert, 2011, №18 (752).

5. Pavlovskij G. Novaja politkorrektnost' - protiv jazyka vrazhdy // Russkij zhurnal, 2010, 22 nojabrja.

6. Otnoshenie rossijan k policii // Press-reliz Analiticheskogo Centra Jurija Levady (Levada-Centr), 2016, 11 nojabrja.

7. Sostojanie prestupnosti v Rossii: Statisticheskij sbornik za 2010-2016gg. GIAC IVD Rossii. 2017.

8. Cit. po: Bezvol'nye predlozhenija. Predstaviteli samoj krupnoj frakcii Gosdumy vyskazalis' protiv proekta amnistii // Rossijskaja gazeta, 2011, 1 ijunja.

9. Sonin K. Pravila igry: Posledstvija straha // Vedomosti, 2010, № 215 (2733), 15.11.

10. Shulepova E. Mjerov b'jut molcha. V Rjazanskoj i Tul'skoj oblastjah izbili glav municipal'nyh // Rossijskaja gazeta - Federal'nyj vypusk, 2010, №5357 (278) ot 9 dekabrja.

11. Konstitucija Rossijskoj Federacii, prinjataja referendumom 12 dekabrja 1993 goda s izm i dop 2009 i 2014gg. // Rossijskaja gazeta. 1993. 25 dekabrja.

12. Cit. po: Donath K.-H. Dmitri Muratow über den Fall Chodorkowski "Die Oligarchen sind fetter geworden" // Die Tageszeitung, 2010, 15.12

13. Zelik V.A. Osnovnye tendencii vlijanija nezakonnogo potreblenija narkoticheskih sredstv i psihotropnyh veshhestv na prestupnost'. Politematicheskij setevoj jelektronnyj nauchnyj zhurnal Kub GAU. 2014. № 104; Zelik V.A., Jablochkin A.E. Osobennosti semejno-bytovyh prestuplenij, sovershaemyh v sostojanii op'janenija // Obshhestvo i pravo. 2014. № 4 (50). S.170-174.

14. Koshkina A. Sovetnik predsedatelja Konstitucionnogo suda RF general-major milicii v otstavke Vladimir Ovchinskij «Organizovannaja prestupnost' beschinstvuet v bol'shinstve regionov Rossii» // Novye Izvestija, 2010, 25 nojabrja.

15. Koshkina A. Sovetnik predsedatelja Konstitucionnogo suda RF general-major milicii v otstavke Vladimir Ovchinskij «Organizovannaja prestupnost' beschinstvuet v bol'shinstve regionov Rossii» // Novye Izvestija, 2010, 25 nojabrja.

16. Samarina A. Ubijstvo kak zasada dlja vlasti. Medvedevu nado chto-to delat', inache kriminal'naja revoljucija nakonec pobedit// Nezavisimaja gazeta, 2010, 30 nojabrja.

17. Kratkij filosofskij slovar' / avt. A.P. Alekseev, G.G. Vasil'ev i dr. / pod red. A.P. Alekseeva. -M., 1955. S. 355.

18. Ob obrazovanii v Rossijskoj Federacii: Federal'nyj zakon ot 29.12.2012 № 273-FZ s izm i dop. // Rossijskaja gazeta. 2012. 30 dekabrja.

19. Ob osnovah sistemy profilaktiki pravonarushenij v Rossijskoj Federacii: Federal'nyj zakon ot 23 ijulja 2016g. № 182-FZ // Rossijskaja gazeta. 2016. 25 ijunja. 